\title{
LAND SUBSIDENCE AND ITS EFFECTS ON THE URBAN AREA OF TEPIC CITY, MEXICO
}

\author{
WILLIAM H. HERRERA LEÓN ${ }^{1}$, JESÚS PACHECO MARTÍNEZ ${ }^{2}$, MARTÍN HERNÁNDEZ MARÍN ${ }^{3}$, \\ RAUDEL PADILLA CENICEROS ${ }^{2} \&$ MARÍA DE LA LUZ PÉREZ REA ${ }^{4}$ \\ ${ }^{1}$ Centro de Ciencias del Diseño y de la Construcción, Universidad Autónoma de Aguascalientes, Mexico \\ ${ }^{2}$ Departmento de Construcción Estructuras, Universidad Autónoma de Aguascalientes, Mexico \\ ${ }^{3}$ Departmento de Geotecnica y Hydraulica, Universidad Autónoma de Aguascalientes, Mexico \\ ${ }^{4}$ Ingeniería, Universidad Autónoma de Querétaro, Mexico
}

\begin{abstract}
Fresh water is one of the natural resources needed for supply of urban, industrial and agricultural development; and its scarcity could be critical for urban growth. In the last decades, ground water exploitation has had a great negative impact in arid and semi-arid areas around the world, where groundwater is the only source for fresh water and the aquifer system is composed of unconsolidated sediment. Intense groundwater extraction results in a drop in the groundwater level, which in turn induces the gradual subsidence of surface terrain, due to the compaction of unconsolidated sediments. This phenomenon known as subsidence is due to groundwater extraction, and currently several alluvial and lacustrine valleys with large growing cities around the world are undergoing its effects. When the aquifer system lies on bedrock with irregular topography, uneven settlement is generated, leading to the occurrence of surface ground failures that damage both urban infrastructure and housing. Tepic City is a growing city located in an incipient subsidence area in central West Mexico. Even though the subsidence process in Tepic City was detected in 2014, the local government agencies responsible for urban planning have not realized this new hazard for city growth, and consequently there are still no regulations for new urban developments that may become exposed to subsidence effects. Herein we analyze and discuss the relationship between natural factors and anthropogenic ones which have conditioned and triggered the subsidence process in the Tepic area. Additionally, we present a description of the current effects of subsidence on the urban areas of Tepic City, and discuss subsidence damages' expected evolution if no actions are undertaken for their mitigation and prevention.
\end{abstract}

Keywords: aquifer, groundwater, bedrock, groundwater extraction, failures, Mexico, sinking land, subsidence, Tepic City.

\section{INTRODUCTION}

Subsidence is the gradual settlement of large areas of the earth's surface. This phenomenon has its origin in the extraction of subsoil resources, whether minerals, hydrocarbons, gas or water. In Mexico, reported subsidence is mainly caused by the extraction of water from granular aquifers, which are exploited in order to supply potable water to urban, industrial and agricultural centers, resulting in a strong anthropogenic impact that is manifested by differential land settlement. In Mexico, this phenomenon is concentrated in the transMexican volcanic belt (except for some cases in the north of the country), mainly geological structures of the graben type that over time were filled with alluvial or lacustrine water carried there, forming fertile valleys suitable for agriculture or livestock. Since the last century, subsidence and cracking of the surface occurs in different valleys and coasts around the world [1], [2], affecting mainly urban areas where there is a greater probability of damage to infrastructure, housing areas, productive plant and industrial zones, etc. Subsidence, its causes and its effects have been documented, investigated and discussed in different scientific forums around the world [1]-[8]. 
Burbey [9] mentioned the climatic and geohydrological conditions associated with zones prone to present subsidence and ground failure. Some of these conditions occur in the Matatipac Valley, among which are:

a) The Valley is part of the Tepic-Zacoalco graben (Fig. 1) that has NW-SE orientation and extends from the Chapala Lake in Jalisco until San Blas Nayarit [10], [11].

b) The filling material of the Matatipac Valley comprises quaternary and tertiary volcanic materials of little to medium consolidation.

c) Although there is no arid or semi-arid climate in the Matatipac Valley area, the volume of water recharged to the aquifer is less than the volume of water extracted.

d) As a consequence of the previous point, there has been a decline in static levels that is due to excessive pumping of groundwater.

In the studied area, the most notorious hydrographic feature is the Mololoa River, which crosses the Matatipac Valley from south to north. The secondary surface currents are the streams Las Cuevas, El Puente Grande, El Cordoncillo, El Llorón de Mora, San Francisco and Mal Paso, among others that discharge their waters to the Rio Grande de Santiago. All of them are tributaries of the Mololoa river that lead the precipitated water in the high parts that surround the Valley to the low part [12]-[14].

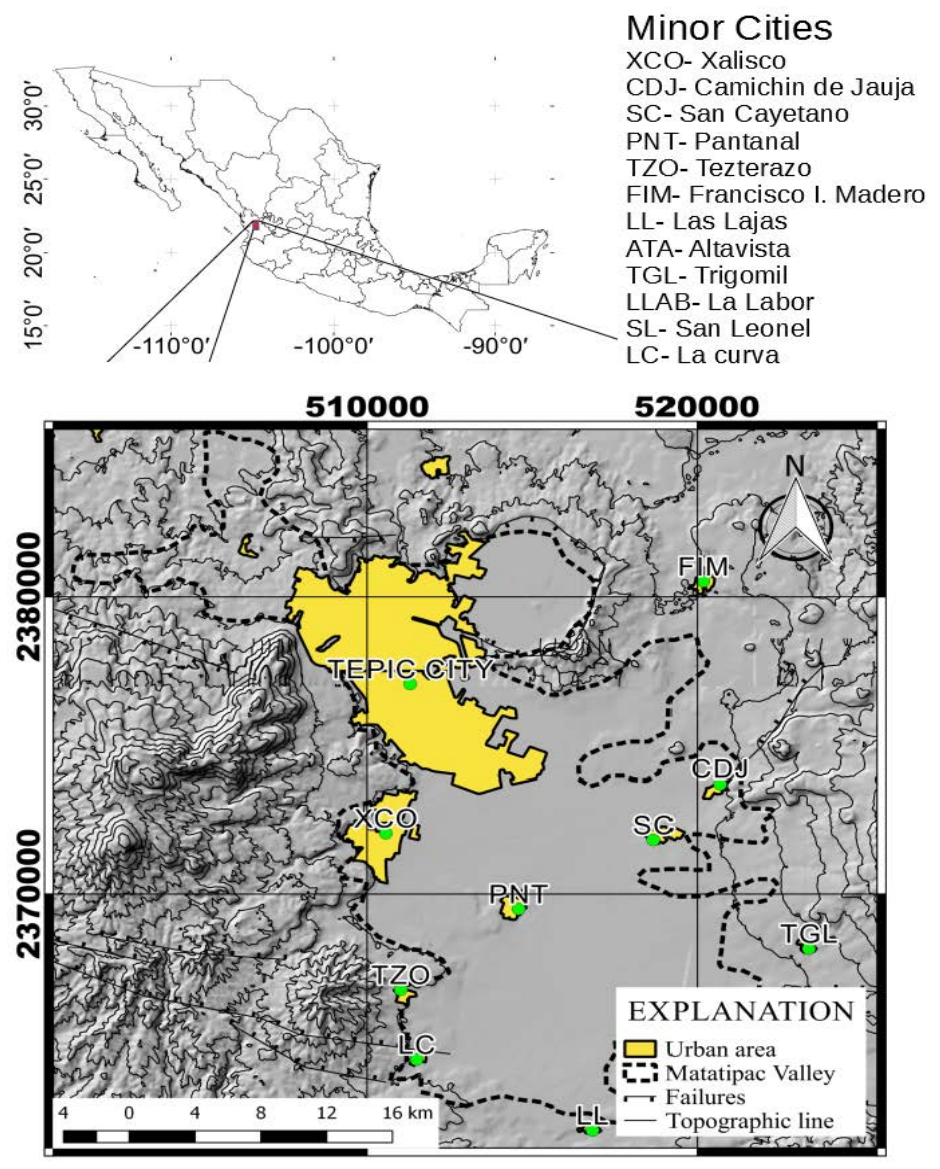

Figure 1: Map showing location of Matatipac Valley and Tepic City. 
Despite the existence of surface currents, in recent decades the use of groundwater was favored because it is more economical to drill a shallow well than to construct hydraulic works for the use of surface water currents. In the region studied, the average annual rainfall is $1245 \mathrm{~mm}$, which is less than the average annual evapotranspiration potential $(1700 \mathrm{~mm})$. According to this, the potential for recharging the aquifer naturally is limited and depends on the speed with which the water infiltrates the subsoil, thus preventing its evaporation. Regarding the hydrogeology of the Matatipac Valley: Although the local government and the federal office in charge of the administration of water resources have carried out exploratory and hydraulic water studies, much of the information is lost in the archives of different government agencies involved. Although this type of information is public in Mexico, its access is delayed and difficult because the government agencies do not have a program or initiative to publicize the type of studies they have, their special and temporary coverage, or the results achieved to date. Hence, this work presents information that was generated in several unpublished and published technical reports about the Matatipac Valley aquifer. The information presented is aimed at explaining the subsidence process that is currently presented and its current consequences. It also presents an analysis and a discussion about the expected effects due to subsidence and fracture of the land in the urban development, if the same tendency of exploitation of the aquifer continues.

\section{GEOLOGY OF MATATIPAC VALLEY}

The Matatipac Valley is located in the geological province of the trans-Mexican volcanic belt (FVTM) which is a magmatic arch from the mid-late Miocene [15], [16], which forms a $16^{\circ}$ angle with the Mesoamerican Trench [17]. The FVTM extends from the coast of the state of Veracruz and ends in the town of San Blas in the state of Nayarit [10], [11]. This physiographic province is divided into three sections [10], [16] (Fig. 2): a western section that extends from San Blas in the state of Nayarit and includes the Jalisco block [18]; another central section that begins at the western boundary of the Jalisco block and is limited to the Taxco-San Miguel de Allende fault system [19]; finally, an eastern section that extends from this fault system to the Gulf of Mexico [17].

The Matatipac Valley is located in the western sector of the FVTM and is part of the Jalisco block that is delimited on the continent by three extension structures [20], which are: the graben of Colima, the graben of Chapala and the Graben Tepic-Zacoalco [21], [22]. The Tepic-Zacoalco graben was formed by an extension regime during the Pliocene-Quaternary period [23]-[26], which is a cortical structure with an approximate NW direction, where its faults have an approximate distance of $250 \mathrm{~km}$ and a width between them of $50 \mathrm{~km}$ [27]. It is constituted of a series of graben and semi-graben, which are divided [15], [28] into:

a) The Pochotitan fault system located at the NW, which is a system of normal listric faults at a high angle of inclination, with N-NE orientation;

b) Rift steps that are in the center and that consist of two graben called CompostelaCeboruco and the graben Plan de Barrancas-Santa Rosa;

c) Faults localized in the Jalisco Block conformed by a semi-graben called Amatlán de Cañas.

Within the Pochotitan fault system is the Matatipac Valley, the subject of this study. Broadly speaking and according to the Mexican Geological Survey (Fig. 3), the geology is described below in order from the oldest units to the most recent ones.

Rhyolites (TmplTR-R). They are overlying the andesitic rocks and ignimbritic tuffs that appear in the form of spills and dome bodies of a fluid structure, pseudo-stratified with abundant obsidian fragments. 


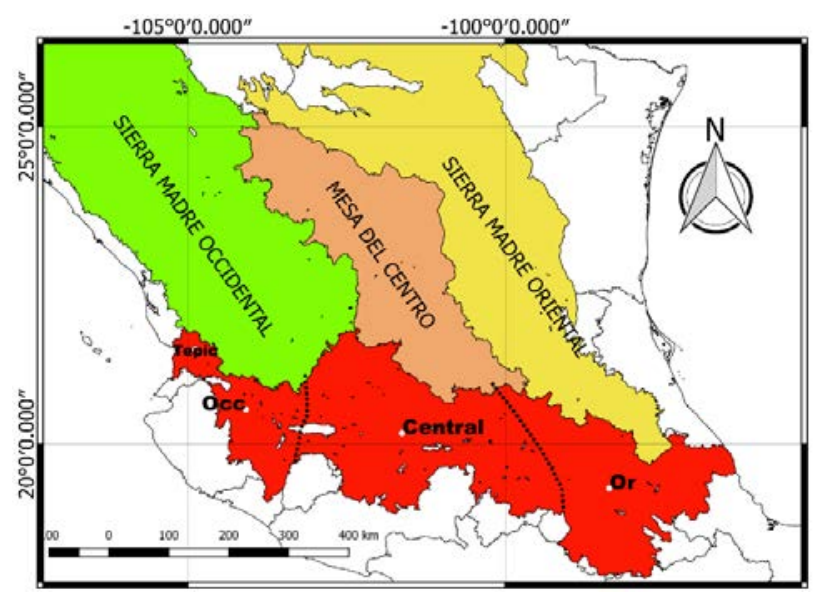

Figure 2: Trans-Mexican Volcanic Belt: (Occ) occidental or West; central; and (Or) oriental or East.

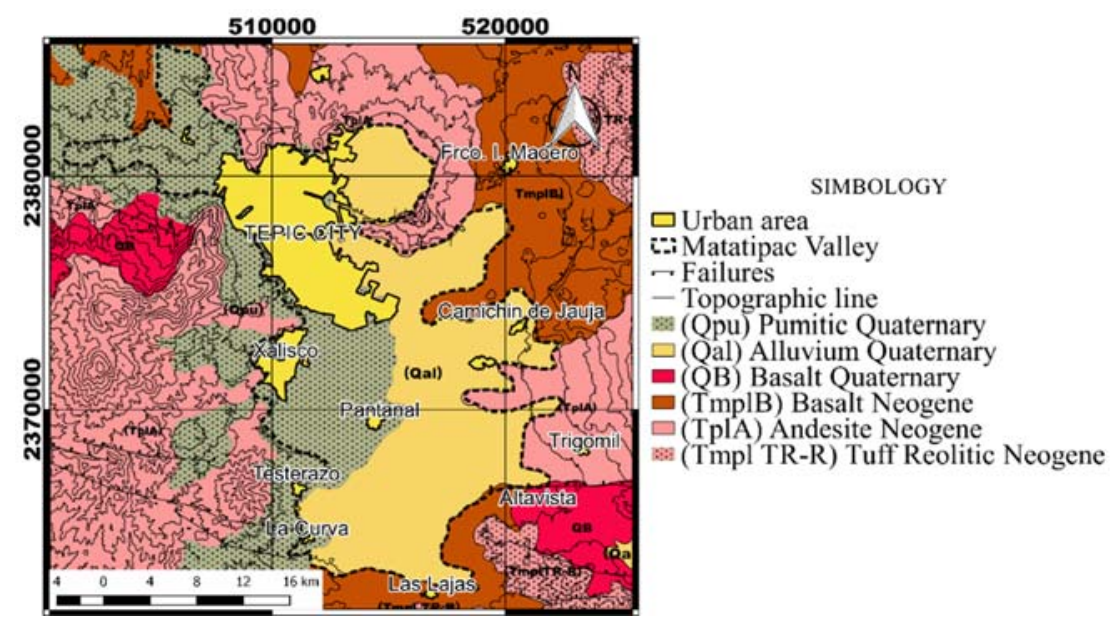

Figure 3: Geology of Matatipac Valley.

Basaltic Andesites (TplA). These rocks are found in the eastern part of the area, forming complex structures such as the Sangangüey Volcano and others of minor importance, of basaltic composition; The representative rocks of this unit present textures from aphanitic to porphyry, with a compact structure and dark gray color that intertwines to greenish gray. An age of the Pliocene is attributed to it.

Basalts (TmplB). These rocks are located in the eastern part of the Valley and comprise the young volcanic rocks, represented by wide plateaus of considerable thickness, which are observed as accumulations of dense spills that cover the pre-existing relief. They have an aphanitic texture that varies from vesicular, with crystals somewhat altered by their exposure to atmospheric agents; and are observed at certain points, covered by thin layers of pyroclastic material. 
Basalts $(Q B)$. They constitute the most recent volcanic emissions in the Valley and are represented by conical apparatuses and coriaceous bodies, distributed in dispersed form, but some follow superficially masked fault lines.

Alluvium and Soils (Qal). This group includes accumulation materials formed by the alteration and disintegration of pre-existing rocks exposed to air, humidity and the effects of organic matter. Its composition is limo-clayey and little consolidated fragments of pumice. It is found in the superficial part of the entire stratigraphic column described.

Pumicites $(Q P u)$ Loose or little consolidated materials of pyroclastic origin observed in the western part of the Valley forming thick deposits with alternating layers of fine grains with layers of coarse-grained fragments of pumice composition that originate well-defined, classified pseudo-strata.

Due to the geological conditions in the subsoil, there are no lithological units that define confinement in the areas that report separation between shallow and deep levels [12]. The maximum thicknesses explored in the area of the Valley are from 250 to $300 \mathrm{~m}$; however, no units are reported that should be considered as a basement of the aquifer, so the thickness of the saturated area of the aquifer system is located at 500 or $600 \mathrm{~m}$ in depth, based on the results of the hydrogeochemical analysis of the area [13].

We observed that in the dates of these analyses, the greatest dejection occurs towards the central zone of the Valley, towards the south of the city of Tepic and that the minor ones appear in the northern part of the city. The greater dejection in the central part is because the highest concentration of extraction wells are located in these areas. The average evolution is around -3 to $-4 \mathrm{~m}$ in said period, equivalent to an average annual rate of abatement of up to $0.5 \mathrm{~m} \mathrm{[12].}$

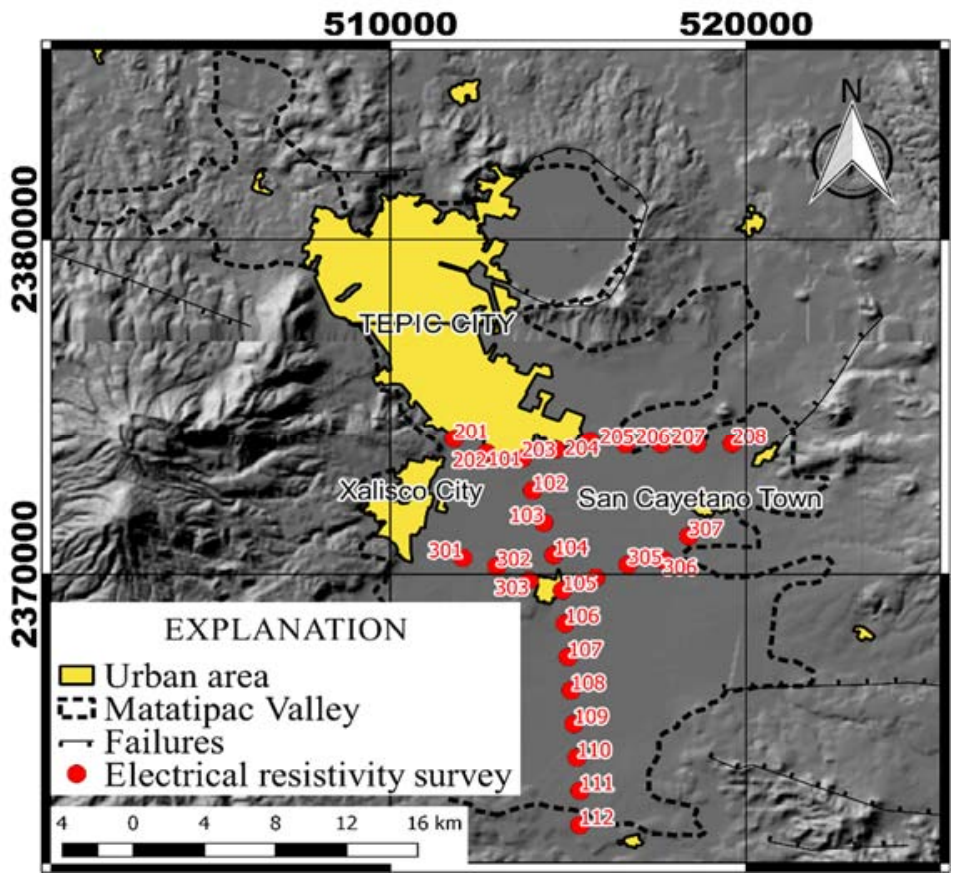

Figure 4: ERS location. 


\section{GEO-HYDROLOGY OF THE MATATIPAC VALLEY}

We obtained three profiles of electrical resistivity survey [13], to which in this work we give a new interpretation: The method used was Wenner. In Fig. 4 the location of the measurements is observed and the nomenclature is the one used in the aforementioned work. The new interpretation allowed us to characterize four hydrogeological units in practically all the profiles, based on the intervals of values of resistivity. The two-dimensional (2D) models of the probes and their interpretation are shown in Fig. 5.

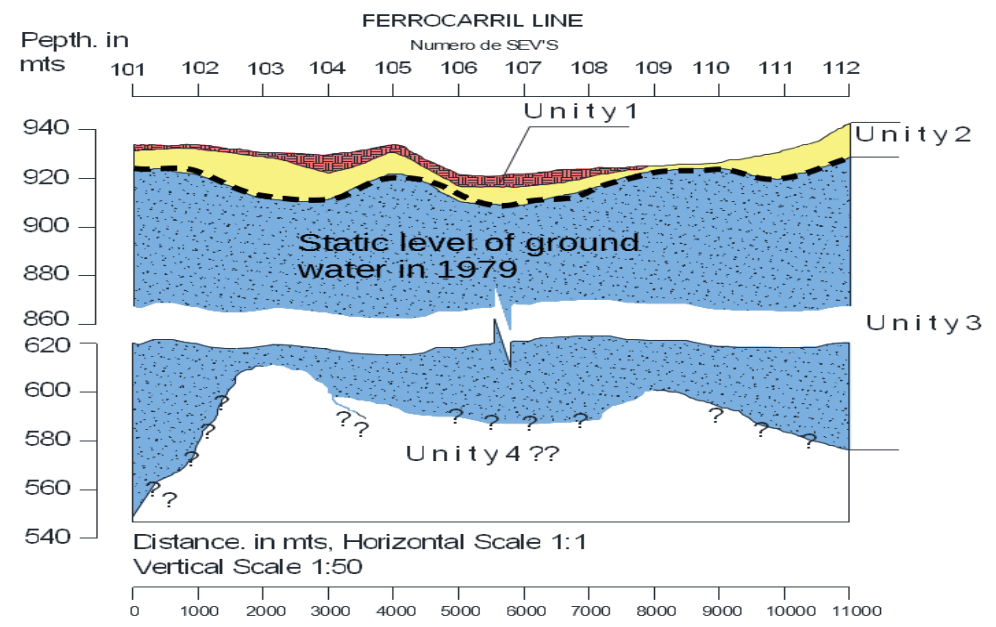

(a)

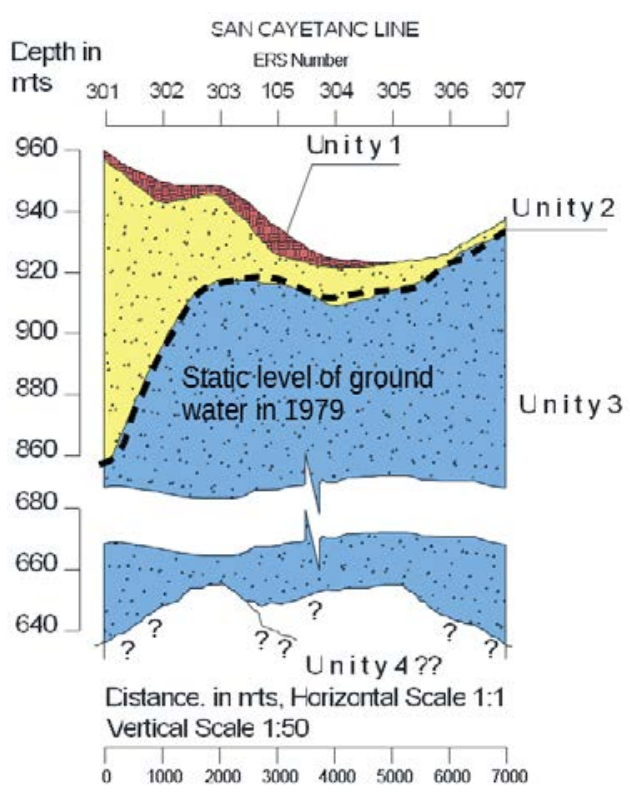

(b)

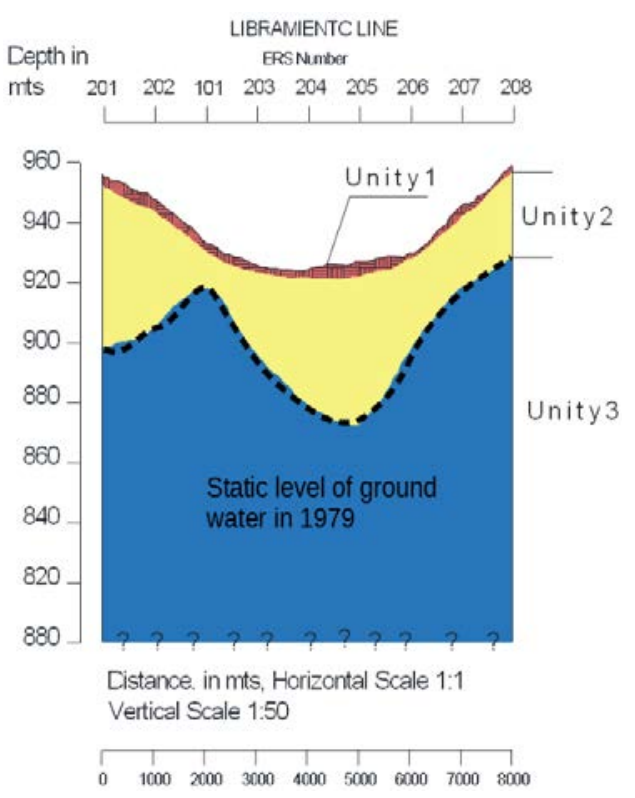

(c)

Figure 5: Interpretations of electrical resistivity survey. (a) Train line; (b) San Cayetano line; and (c) Libramiento Line. 
The ERS show a decrease in resistivity between 10 and 20 meters, which suggests that the water mirror is at this depth and is hosted by the geohydrological units U3 and U4 that are interpreted as the hydrogeological units currently being used. The three profiles have a separation of approximately one kilometer between SEV. In the three profiles, there are three units that are described from the shallowest to the deepest:

Unit 1: Layer associated with alluvium (QAl) of coarse size (sand and gravel) up to 10 meters thick in the "San Cayetano" profile.

Unit 2: Stratum with variable 1-meter thickness in the railway profile, up to $100 \mathrm{~m}$ to the west on the San Cayetano profile. It is associated with the vadose zone of alluvium (QAl) and the pumice fillings (Qpu).

Unit 3: The low resistivity values of this stratum suggest that it is saturated, which is why it is considered to be the hydrogeological unit producing the Valley's aquifer.

It is composed of alluviums (QAl) from medium to coarse with pumice sands of volcanic origin (Qpu). The SEVs do not register the lower contact of this stratum, so its thickness is unknown.

The fourth unit could not be identified. In Fig. 6 it is observed that the variation of the static levels are in a range of 1 to 9 meters. The abatement comprises the period from May 1985 to April 2003 [12].

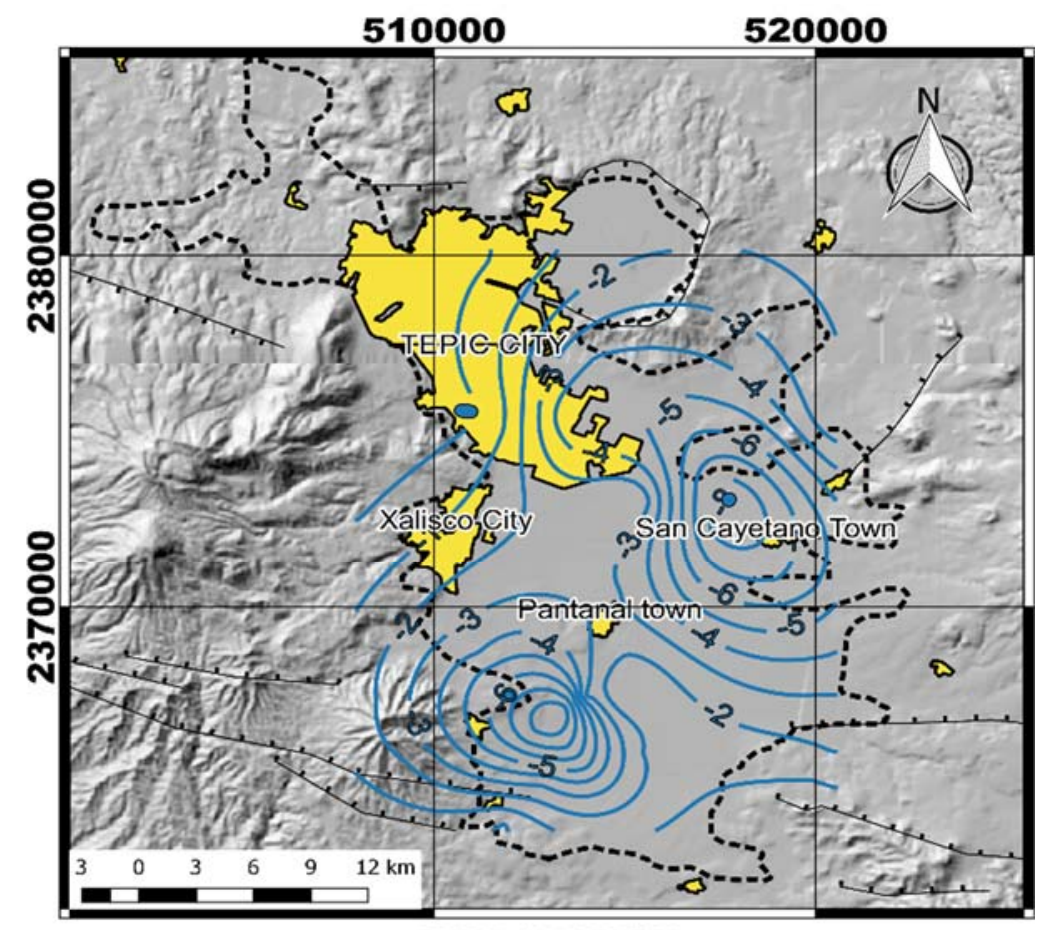

EXPLANATION

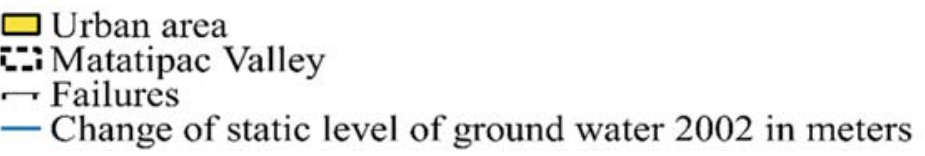

Figure 6: Changes in static level of ground water, 1985 to 2002, in meters. 


\section{FIRST REPORTS OF DAMAGE RELATED TO THE DEFORMATION OF THE LAND IN THE MATATIPAC VALLEY}

The subsoil of the Matatipac Valley is a mixture of materials from different geological eras deposited in the depression formed by the Tepic graben. The materials are homogeneous mixtures of alluviums of coarse to medium sizes, as well as pumicy material, breccias, sands of saturated volcanic origin, silts and clays. In geotechnical studies it is common to obtain values of $\mathrm{N} 60<25$, specific weights of $4400 \mathrm{~N} / \mathrm{m}^{3}$, and Liquid Limit 25 or nonexistent; plus removals of up to $115 \%$ of their weight. The surface material is quite favorable for the construction of foundations because its load capacity is relatively high.

The damage caused by this phenomenon has not been quantified, because the phenomenon has not been sufficiently noticeable to alarm governments or those affected; however, for the year 2014 a study was published [29] where the situation of several cities of the country located in the Mexican volcanic belt is described, cities with a population of over 100,000 inhabitants and displaced on compressible landfills, cities such as: Morelia, Aguascalientes, Mexico City, Celaya, Querétaro, Irapuato, San Luis Potosí, Ahuacatlan and Tepic, among others.

SAR images of the ALOS satellite were used between 2007 and 2011, for the city of Tepic in particular, and the acquisitions used were from April 30, 2007 to December 24, 2011: with this we obtained a map of the average speeds and active deformation and areas are identified in Fig. 7(a); the positive velocities are observed in blue, which means movement towards the satellite, and the negative velocities in red represent subsidence. In Fig. 7(b), the speed of the vertical movement in $\mathrm{cm}$ is shown in three different points within the city of Tepic.

In the city of Tepic, the area affected by subsidence is approximately $20 \mathrm{~km}^{2}$ and occurs in a distributed manner throughout the urban area (it has a range of up to $7 \mathrm{~cm}$ of subsidence per year), is concentrated in the urban centers of Tepic and Xalisco.

There is no report of subsidence in the areas of agricultural exploitation, it is delimited by the San Juan volcano to the west and the Mololoa River to the east of the city, also points of subsidence are detected within what is the Caldera de Tepic in what is known as La Laguna (the lake).

On the other hand, no cracking of the associated land is reported; however, there is evidence of cracking in SE Tepic, which crosses several colonies and the building where the offices of transit and highway of the state of Nayarit are housed. The evidence is not conclusive; however, a survey was made of deterioration of urban infrastructure such as sidewalks, planters, ruptured pipes and walls in houses, among others: a pattern of damage was discovered that coincides with the maximum speed gradients in the Chaussard map, which gives suspicion about the genesis of cracking in this area (Fig. 8). The differential deformation that occurs is only a few centimeters, so for the untrained eye it can be unnoticed; however, it has all the characteristics of an incipient fracture due to subsidence, due to loss of hydraulic support on a rocky structure of topography, uniform and non-deformable.

The first image used to perform the interferogram was from 2007 and the last one from 2011: it is expected that in years of lag, the configuration of the abatements would be different. If we take the rate of abatement that occurred when the analysis of the aquifer was done, which is approximately $50 \mathrm{~cm}$ per year, it would have to be for the year 2011, the date of the last image of the interferogram in the area near the Technological Institute of Tepic (one of the most affected): the abatement would decrease from -3 meters to -5.5 meters and from -4 meters to -6.5 meters, approximately. This assumption of abatement is quite conservative, since it is to be expected that the rate of abatement has grown exponentially in recent years. 
(a)

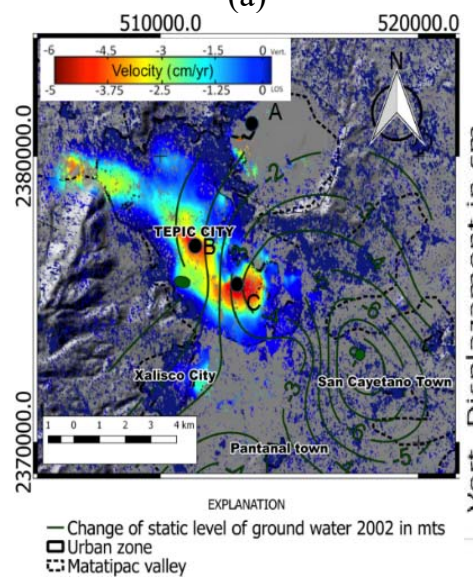

(b)

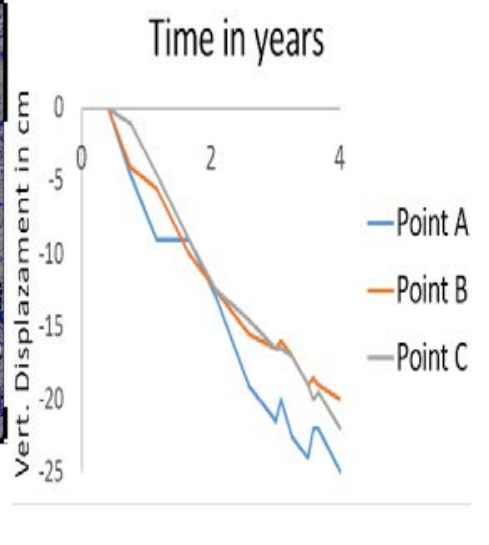

Figure 7: (a) Map of velocity; (b) Vertical displacement per year in 3 points. (Source: modified from Chaussard et al.)

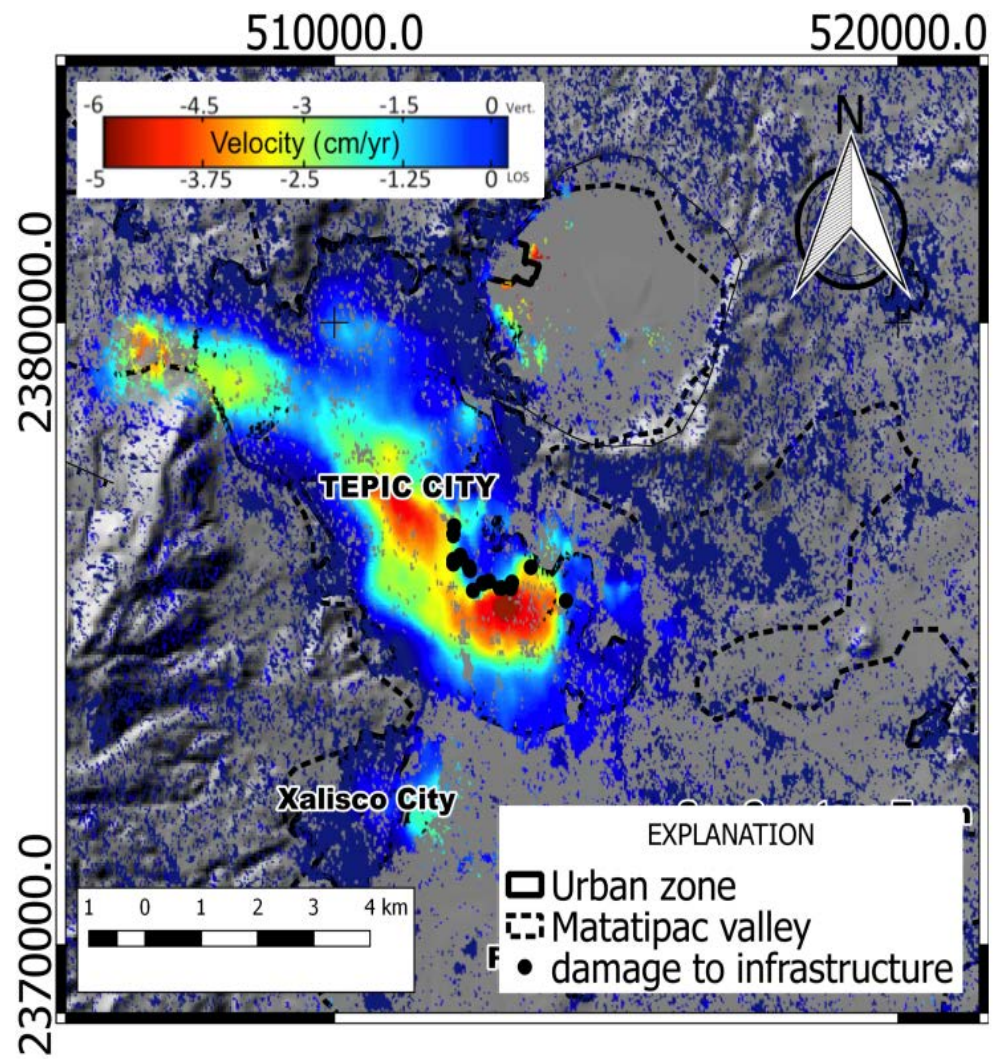

Figure 8: Infrastructure damage in Tepic City. 


\section{SUMMARY AND CONCLUSIONS}

Subsidence of the land, as well as the supposed cracking that occurs in the Matatipac Valley, is a problem that involves several factors that favor the occurrence of deformation of the surface of the land. It can be summarized that there is a granular aquifer system with undefined, unconfined compressibility; intensive pumping of groundwater that exceeds the natural recharge; and an irregular topography of the underlying bedrock of unknown depth. The hydrogeology of the Valley is represented by undefined granular aquifers that have been heavily depleted since the 1980s. The manifestations of surface deformation include differential land subsidence, with maximum recorded rates of $6-7 \mathrm{~cm} / \mathrm{yr}$. The problem has not been addressed by the local government, as the damages to infrastructure and individuals have not generated alarm in the population; however, due to the continuous growth of the city of Tepic, as well as of its conurbated zones, increasing demand for groundwater resources will continue in the future. As a result, it is likely that the sinking will continue and related ground failures will appear.

There is inconclusive evidence of cracking forming in the southern part of the city, which crosses human settlements, road infrastructure, and urban equipment, among others.

It is imperative that measures are taken to minimize economic losses related to the problems of collapse, among which we can mention: update construction designs to make them more resistant to the effects of the deformation of the land; and encourage research that leads to greater knowledge of the form and composition of the aquifer system, as well as its piezometric evolution, so that accurate numerical models can be developed that lead to better analysis and prediction of the land subsidence process.

\section{REFERENCES}

[1] Steedman, R.S., Multi-disciplinary assessment of subsidence phenomena in the ravenna area. Proceedings of the Seventh International Symposium on Land Subsidence, Shanghai, P.R. China, p. 192, 23-28 Oct. 2005.

[2] Carreón-Freyre, D., Cerca, M., Galloway, D.L. \& Silva-Corona, J.J., Land Subsidence, Associated Hazards and the Role of Natural Resources Development, IAHS Press, p. 522, 2010.

[3] Group 8.4 IHPW, Guidebook to Studies of Land Subsidence due to Ground-Water Withdrawal, Unesco, p. 346, 1984.

[4] Barends, F.B.J., Brouwer, F.J.J. \& Schröder, F.H., Land subsidence: by fluid withdrawal, by solid extraction: theory and modelling, environmental effects and remedial measures. Proceedings of the Fifth International Symposium on Land Subsidence, The Hague, the Netherlands, p. 528, 16-20 Oct. 1995.

[5] Prince, K.R., Galloway, D.L. \& Leake, S.A., U.S. geological survey subsidence interest group conference, Edwards Air Force Base, Antelope Valley, CA, 18-19 Nov. 1992: abstracts and summary. The Survey, p. 96, 1995.

[6] U.S. geological survey subsidence interest group conference. Proceedings of the Technical Meeting, Las Vegas, Nevada, 14-16 Feb. 1995, p. 48, 1997.

[7] US geological survey (USGS). Open file report 03-308. USGS subsidence interest group conference. Proceedings of the Technical Meeting, Galveston, Texas, 27-29 Nov. 2001, Department of Interior: Austin, Texas. https://pubs.usgs.gov/of/2003/ ofr03-308/pdf/OFR03-308.pdf. Accessed on: 24 Jan. 2018.

[8] Borchers, J.W., Land Subsidence Case Studies and Current Research. Proceedings of the Dr. Joseph F. Poland Symposium on Land Subsidence, 1998.

[9] Burbey, T.J., The influence of faults in basin-fill deposits on land subsidence, Las Vegas Valley, Nevada, USA. Hydrogeol J., 10(5), pp. 525-538, 2002. 
[10] Demant, A., Características del Eje Neovolcánico Transmexicano y sus problemas de interpretación. Rev Mex Cienc Geológicas, 2(2), pp. 172-187, 1978.

[11] Demant, A., A preliminary report on the comenditic dome and ash flow complex of Sierra La Primavera, Jalisco. Rev Mex Cienc Geológicas, 2, pp. 218-222, 1978.

[12] CONAGUA, Actualización de la disponibilidad media anual de agua subterránea acuífero (1804) Valle de Matatipac, estado de Nayarit, 2003.

[13] SARH, Estudio Geohidrológico Preliminarde las zonas de Matatipac-Zacualpan y Las Varas, Nayarit, 1980.

[14] CONAGUA, Informe del Modelo Matemático de Simulación del Acuífero del Valle de Matatipac, Estado de Nayarit, 1992.

[15] Ferrari, L., Pasquarè, G., Venegas-Salgado, S. \& Romero-Rios, F., Geology of the western Mexican volcanic belt and adjacent Sierra Madre Occidental and Jalisco block. Cenozoic Tecton Volcanism Mex., 65, p. 334, 1999.

[16] Pasquaré, G., Garduno, V.H., Tibaldi, A. \& Ferrari, M., Stress pattern evolution in the central sector of the Mexican volcanic belt. Tectonophysics, 146(1), pp. 353-364, 1988.

[17] Gómez-Tuena, A., Orozco-Esquivel, M.T. \& Ferrari, L., Igneous petrogenesis of the Trans-Mexican Volcanic Belt. Special Paper 422: Geology of México: Celebrating the Centenary of the Geological Society of México. Geological Society of America, Online. https://pubs.geoscienceworld.org/books/book/581/chapter/ 3803636/. Accessed on: 14 Dec. 2017.

[18] Allan, J.F., Geology of the Northern Colima and Zacoalco Grabens, southwest Mexico: Late Cenozoic rifting in the Mexican volcanic belt. GSA Bull., 97(4), pp. 473-485, 1986.

[19] Alaniz-Álvarez, S.A., Nieto-Samaniego, A.F., Morán-Zenteno, D.J. \& Alba-Aldave, L., Rhyolitic volcanism in extension zone associated with strike-slip tectonics in the Taxco region, southern Mexico. J. Volcanol. Geotherm. Res., 118(1), pp. 1-14, 2002.

[20] Stock, J.M., Tectónica de placas y la evolución del Bloque Jalisco, México. GEOS., 13(3), pp. 3-9, 1993.

[21] Bourgois, J. \& Michaud, F., Active fragmentation of the North America plate at the Mexican triple junction area off Manzanillo. Geo-Mar. Lett., 11(2), pp. 59-65, 1991.

[22] Luhr, J.F., Nelson, S.A., Allan, J.F. \& Carmichael, I.S.E., Active rifting in southwestern Mexico: Manifestations of an incipient eastward spreading-ridge jump. Geology, 13(1), pp. 54-57, 1985.

[23] Nieto-Obregon, J., Urrutia-Fucugauchi, J., Cabral-Cano, E. \& de la Campa, A.G., Listric faulting and continental rifting in western Mexico - A paleomagnetic and structural study. Tectonophysics, 208(4), pp. 365-376, 1992.

[24] Legorreta, O.Q., Michaud, F., Bourgois, J. \& Barrier, E., Evolución de la frontera septentrional del bloque de Jalisco, México. Rev. Mex. Cienc. Geológicas, 10(2), p. 2, 1993.

[25] Ferrari, L., Pasquare, G., Venegas, S., Castillo, D. \& Romero, F., Regional tectonics of western Mexico and its implications for the northern boundary of the Jalisco block. Geofisica Int., 33(1), pp. 139-151, 1994.

[26] Rosas-Elguera, J., Ferrari, L., Garduño-Monroy, V.H., \& Urrutia-Fucugauchi, J., Continental boundaries of the Jalisco block and their influence in the PlioceneQuaternary kinematics of western Mexico. Geology, 24(10), pp. 921-924, 1996.

[27] Frey, H.M., Lange, R.A., Hall, C.M., Delgado-Granados, H. \& Carmichael, I.S., A Pliocene ignimbrite flare-up along the Tepic-Zacoalco rift: Evidence for the initial 
380 Urban Growth and the Circular Economy

stages of rifting between the Jalisco block (Mexico) and North America. Geol. Soc. Am. Bull., 119(1-2), pp. 49-64, 2007.

[28] Rosas-Elguera, J., Late Miocene to Quaternary extension at the northern boundary of the Jalisco block, western Mexico: The Tepic-Zacoalco rift revised. Cenozoic Tecton Volcanism Mex., 41, p. 334, 2000.

[29] Chaussard, E., Wdowinski, S., Cabral-Cano, E. \& Amelung, F., Land subsidence in central Mexico detected by ALOS InSAR time-series. Remote Sens. Environ., 140(Suppl. C), pp. 94-106, 2014. 